\title{
Is Western Marxism Western? \\ The Cases of Gramsci and Tosaka*
}

\section{TAKAHIRO CHINO}

Waseda University, Japan (t.chino@waseda.jp)

\begin{abstract}
This paper aims to show that two eminent Marxists in the 1930s, the Italian Antonio Gramsci and the Japanese Tosaka Jun, shared three important characteristics of so-called Western Marxism: the methodological development of Marxism, the focus on the superstructure, and the pessimism about the impossibility of immediate revolution. Showing that Gramsci and Tosaka shared these characteristics enables us to revisit the framework. of "Western Marxism," which confusingly consists of both theoretical characteristics and geographical criteria. Looking at Gramsci and Tosake on the same plane allows us to revisit Marxist thought different from the orthodox Marxism in Soviet Russia, and not strictly as a Western, but as a part of potentially global movement of thought.
\end{abstract}

Keywords: Marxist Philosophy; Western Marxism; Antonio Gramsci; Tosaka Jun; Global Intellectual History

\section{$1 \quad$ Introduction}

This article shows that two eminent Marxists in the 1930s, the Italian Antonio Gramsci (1891-1937), and the Japanese Tosaka Jun (1900-1945) ${ }^{1}$, have provided considerably similar theories, which we acknowledge as those of Western Marxism in terms of its three key features: the methodological development of Marxism, the focus on the superstructure, and political pessimism about the possibility of future revolution. The case of Tosaka exemplifies that these key features of Western Marxism can also be found in geographically non-Western Marxists of the same era, irrespective of mutual contact, enabling us to revisit the commonly accepted framework of Western Marxism, which—confusingly—entails both theoretical characteristics and geographical criteria. The geographical element comes to the forefront in determining what does not count as Western Marxism, drawing boundaries behind those theoretical characteristics that were shared beyond these boundaries ${ }^{2}$. If we try to do justice to the theoretical distinctiveness of Western Marxism, instead of endorsing its geographical criteria, Tosaka's case may suggest that, during the early twentieth century, the theoretical characteristics shown in this paper simultaneously develop in Japan, at least. Both Italy and Japan during this period experienced the rapid introduction of a capitalist economy, which created the division of cities and rural areas that appeared as the Southern Question, the division between the poor South and the rich North, in Italy and as the problem of Northern peasants, who were also in severe poverty, in Japan. Italy and Japan, although geographically understood as a part of West and East respectively, also experienced the rise of fascism as a consequence of widespread contradictions caused by rapid industrialization and militarization and the fall of parliamentary liberal democracy. In this sense, looking at Gramsci and Tosaka on the same plane allows us to revisit Marxist thought different from the orthodox Marxism in Soviet Russia, and not strictly as a Western, but as a part of potentially global movement of thought. 
Gramsci's Prison Notebooks have enjoyed worldwide popularity, inspiring the social sciences and humanities with, among others, the ideas of hegemony, passive revolution, and subaltern groups. The ideas that he deployed to analyze Italian politics from the Risorgimento up until his time were found useful in understanding the contemporary world by postwar scholars. By contrast, Tosaka has remained underexplored in and outside of Japan, ${ }^{3}$ perhaps because of the triumph of liberalism in the postwar Japanese intellectual and political climate as embodied by Maruyama Masao (1914-1996). ${ }^{4}$ Recently, however, commentators outside of Japan have revisited Tosaka as a radical social critic whose analysis and theory were groundbreaking in the tradition of Marxist philosophy. ${ }^{5}$ In my view, Harry Harootunian initiated this reappraisal, stating that Overcome by Modernity-Harootunian's masterpiece on interwar Japanese thought - is in a way “an attempt to retrieve Tosaka's powerful critique of fascism and how its ideological appeal to culture and community was sanctioned by a liberal endowment" 6 . Likewise, the editors of Tosaka's English anthology refer to his works as a "powerful corrective" to the category of Western Marxism 7 . Harootunian and other commentators have often referred to the similarity between Tosaka and Gramsci concerning their shared focus on the cultural sphere in modern societies ${ }^{8}$. Although these references have not provided deeper discussions on Tosaka and Gramsci's affinity, this seems to have greater implications than they might have thought, allowing us to revisit our common understanding of the uniqueness of so-called Western Marxism.

Western Marxism as a theoretical category is ambiguous by definition. It may include thinkers of various inclinations from the first decades of the twentieth century to the present ${ }^{9}$. Perry Anderson famously argues that Western Marxism emerged to tackle the glaring division between socialist theory and the labor movement. As a reflection of the failure of orthodox Marxism, first of all, Western Marxism revolves around philosophical questions such as methodology and epistemology. Second, in contrast to orthodox Marxism, which primarily examines the economic base as a determinant of human society, Western Marxism is strongly concerned with the superstructure, where the above philosophical questions arise, as a relatively autonomous realm from the economy. And thirdly, all these developments of Western Marxism represent its consistent pessimism, in contrast to earlier Marxists such as Karl Marx (1818-1883), Antonio Labriola (1843-1904), and Vladimir Lenin (1870-1924), with a series of serious questions on issues such as the stronger structure of capitalism, the bureaucratization of socialism and perhaps the ambivalence of modernity at large (Anderson 1976: 92-4). After briefly introducing Tosaka Jun, who might not be as famous as Gramsci, the rest of this short article tries to show that the above three features can be found not only in Gramsci, but also in Tosaka, in order to demonstrate that Western Marxism, if we regard it as a series of theoretical inclinations, is not comprised exclusively of thinkers geographically residing in the West.

Two Contexts of Tosaka Jun

Before comparing Gramsci and Tosaka, let us start by briefly introducing Tosaka Jun. It is worth placing him in the contexts of prewar Marxist philosophy in Japan and of the Kyoto School ${ }^{10}$. After being disbanded in 1924, the Japanese Communist Party (hereafter JCP) was re-established in 1926, with two opposing factions: the vanguardism of Fukumoto Kazuo (1894-1983) and the populism of Yamakawa Hitoshi (1880-1958). These were based on their different recognitions of the current Japanese situation stemming from the Meiji Restoration in 1868, the culmination of a series of events that groups of lower class Samurais, with different aims and interests, triggered the subversion of the weakened Tokugawa Shogunate, restored the imperial rule, spurred the subsequent westernization and industrialization of Japan, and thereby connected Japan to worldwide capitalism. Fukumoto, having studied under Georg Lukács and Karl Korsch, advocated the two-stage theory of revolution, according to which a future bourgeois revolution would be necessary before the proletarian. By contrast, Yamakawa recognized the 
Meiji Restoration as a bourgeois revolution, suggesting the coming revolution would be the proletarian. However, the Comintern's rejection of both factions in 1927 cost Fukumoto his previously enormous influence, and Yamakawa, who did not join the re-established JCP from the outset, organized the Rōnō-ha (Workers and Peasants Faction) outside the party. In 1930, some JCP theorists, later labeled as the Köza-ha (Lecture Faction), edited a series of books entitled Lectures on the History of Development of Japanese Capitalism. Partly inheriting Fukumoto's view, they insisted that the coming revolution would be bourgeois, with the abolition of monarchy and the large landowning system. As Marxism at large was severely suppressed by the police, the debate did not last long. Yet these factions nevertheless certainly informed the two mainstreams of prewar Japanese Marxism and echoed even into the postwar period. As I will discuss shortly, Tosaka strangely remained silent about this influential debate, because he focused on Marxism not purely as an economic theory, but as a cultural theory in a broad sense.

Another context of Tosaka's thought is the so-called "Kyoto School," among the philosophers studied at Kyoto University around the renowned philosopher Kitarō Nishida (1870-1945), one of whose aims was to overcome the subject-object distinction, made by Descartes and inherited by Kant and Neo-Kantians, essential to modern Western philosophical tradition, in light of the Eastern philosophical and religious tradition. Pursuing this end made the Kyoto School controversial by paving a way to endorse Japanese warfare from the late 1930s as a struggle to overcome Western modernity. Yet the Kyoto School, vague by definition, comprises a variety of thinkers. In this sense, Tosaka held an elective affinity with the Kyoto School in sharing the interest in overcoming Neo-Kantianism but not Western modernity at large.

Miki Kiyoshi (1897-1945), another Kyoto School thinker, informed Tosaka's Marxist inclination. Miki aimed to shape Marxism as a new science beyond the Neo-Kantian dichotomy. After studying under Heinrich Rickert (1863-1936) and subsequently Martin Heidegger (1889-1976) in order to pursue his study on the philosophy of history, Miki is said to have become a Marxist after coming back to Japan (Tairako 2006: 112-13). He observed that the vanguardist Marxism of Fukumoto did not reflect the political and economic situation in Japan due to its dogmatism and lack of scientific knowledge. Together with Hani Gorō (1901-1083), famous for his translation of Croce's historiographical works, Miki founded the journal Under the Flag of New Science in 1928, which aimed to develop Marxism as a non-dogmatic science. Under the suppression of the leftist movements, Miki was arrested in 1930 for the allegation of financing the illegal JCP, and thus stopped engaging in public activities. The following Alliance of Proletarian Science, established in 1929, was also banned in 1933.

It was in this political situation that Tosaka Jun organized the Research Group for Materialism in 1932, which regularly published Materialism Studies as its journal. Although some members of Tosaka's group were the remnants of the Köza-ba, Tosaka remained silent about the debate on Japanese capitalism at least in his edited works (Harootunian 2001: 137) ${ }^{11}$. As far as I am concerned, the instructive book Lecture on Modern Materialism is his only book that discussed Marxism as an economic theory. In 1934, Tosaka was dismissed from his professorship at Hosei University in Tokyo. Four years later, he was arrested, together with the colleagues of his group, under the Peace Preservation Law that targeted revolutionary actions of communists. However, during his rather short career as a writer, he extensively wrote on scientific methods, space and time, the theory of ideology, and current affairs ${ }^{12}$. Among others, Japanese Ideology (1935), Thought and Custom (1936), and Japan as a Part of the World (1937) are perhaps his best known and most quoted works. It is from his epistemological, methodological, and ideological focuses juxtaposed in these works, rather than economic theory, that the ongoing reappraisal of Tosaka derives his uniqueness.

In the following three sections, I show how Gramsci and Tosaka resemble each other as they embody the three key elements of Western Marxism: 1) methodological developments, 2) focus on the superstructure, and 3) proposals to improve the status quo by going beyond pessimism about the impossibility of immediate revolution. 


\section{Elements of Western Marxism (1): Methodological Developments}

In this section, I demonstrate that both Gramsci and Tosaka uniquely developed Marxist philosophy, differently from the crude economic determinism that, like that of Nikolai Bukharin (1888-1938), presumes the economic condition to determine the formation of human society in the superstructure. While Gramsci developed the idea of "historical bloc" as illustrating the relationship between the economy and superstructure, Tosaka elaborated a theory of ideological formation in the superstructure with his concepts of "character" and "everydayness."

\section{Gramsci: Historical Bloc}

In elaborating his Marxist philosophy, Gramsci developed the concept of the "historical bloc" to explain a certain relationship between the superstructure and the economic base at a certain temporality.

First of all, Gramsci provided us with a sophisticated elaboration about the methodological superstructure-base relationship. For all practical purposes, he first distinguished the economic base from the superstructure, and further divided the superstructure into the two: the state as the locus of violence (e.g. police and military) and civil society as that of consent (e.g. media, church, and school etc.) ${ }^{13}$. He particularly focused on the function of civil society as critical in the formation of modern states. Gramsci is often described notably by Norberto Bobbio as a unique Marxist who advocates the autonomy of the superstructure against the economic base ${ }^{14}$. This is half the truth, however. Gramsci repeated many times in the Prison Notebooks that he derived the thrust of Marxism from Marx's "Preface" to A Contribution to the Critique of Political Economy (cf. Q10II\$6: 1244/SPN: 367; Q11ฐ22: 1422/SPN: 432; Q11ฐ64: 1492/SPN: $371-2)^{15}$. In his reading of the "Preface," Gramsci clarified the economic condition as the primary force in constraining the superstructural phenomena, and emphasized that all social problems in the superstructure could be addressed by exploiting the existing resources, given that "no society sets itself tasks for whose accomplishment the necessary and sufficient conditions do not either already exist or are not at least beginning to emerge and develop" (Q13\$17: 1579/SPN: 177). Gramsci thus underscored the economic condition as the constraining force of the superstructure, yet he did not adopt the economic determinism that orthodox Marxism presupposed. On the contrary, for Gramsci, it is a task of human agency to analyze and address political, social, and cultural problems residing in the superstructure, irrespective of their economic conditions ${ }^{16}$.

Second, Gramsci uniquely noticed the non-synchronicity of the superstructure and the economic base. According to him, the superstructure acts automatically even after the collapse of the economic base from which it was born. He instantiated how this works by showing the still-resilient influence of Catholicism over Italian society (Q10II\41xii: 1322/FS: 398). Even if the economic structure is changed, it does not necessarily follow that the corresponding superstructure is simultaneously obliterated ${ }^{17}$.

These two theoretical entailments inform Gramsci's unique idea of the "historical bloc" to cut out a temporary superstructure-base relationship from history (Q8\$182: 1051-2/PN3: 340). For Gramsci, to recapitulate, the constraints that the economy exercises over the superstructure do not amount to the subordinate nature of the latter. For the superstructure exercises autonomy, albeit within the constraints, and the collapse of the economic structure does not necessitate the immediate corresponding fall of the superstructure. Rather, given that the superstructure autonomously acts after the collapse of its conditioning mode of economy, and thus that these two realms have different tempos, a historical bloc signifies a temporary formation of the superstructure-base relationship appearing at a certain historical moment. 


\section{Tosaka: Character and Everydayness}

Like Gramsci, Tosaka found economic determinism a flawed account of the base-superstructure relationship. At a first glance, Tosaka seems more adamant in confirming the decisive role of the economy than Gramsci. While providing a less unique reading of Marx's "Preface" to $A$ Contribution to the Critique of Political Economy, Tosaka submitted that the mode of production is the final determinant of human thoughts and activities (Tosaka II: 105). Yet Harootunian notes that Tosaka's critical elaboration of Marxism was at odds with the developmental economism shared by the two communist factions, namely Köza-ha and Rōnō-ha (Harootnian 2001: 137). This is certainly true, as Tosaka rejected the assumption that the economy determines the superstructure ${ }^{18}$. Despite his assertion of the economy as the final determinant, Tosaka asserted that consciousness in the superstructure and existence in the economic base influence each other, although noting that the influence of the former on the latter is weaker and less systematic than that of the latter on the former (Tosaka III: 312-3).

A good example of the relative autonomy of the superstructure is found in his observation of the mobilization of people's minds triggered by the Konoe Administration in 1937.

[t]hought is $[\ldots]$ a conception that has a certain organized inclination. Mobilization of thought as such, once exercised, cannot be dismissed so easily. Even if mobilization is dismissed, the thought that has developed through mobilization can hardly be dismissed. Moreover, to a certain extent, this thought would achieve a glowingly systematic development in the direction that it was mobilized ${ }^{19}$.

Tosaka well explicated how mobilization works. Institutions such as schooling, media, everyday public activity - the functions of civil society in Gramscian terms-are fully exploited in order to impose on people the norms of how ordinary, and probably morally good, people are supposed to think and act. Crucially, once they consider imposed ideas of how they ought to think and act as the product of their voluntary will—in other words, once people internalize social norms-it is no longer necessary to utilize external institutions to keep imposing these norms on them. This argument of Tosaka overlaps with Gramsci's view of the autonomy of the superstructure, in particular his description of the Catholic Church, that I have sketched in the previous section. Tosaka's unique development of Marxist philosophy can be more clearly seen in his concepts of "character" (Seikaku) and "everydayness" (Nichijo-ser), which the reminder of this section focuses on.

Tosaka elaborated the key concept of "character," which describes how one's consciousness is constrained by historical and social structures, in order to understand the dual nature of ideology, which straddles both consciousness and existence (or both the superstructure and the economy). He posited ideology as the prime problem of modern times, of which only Marxism can provide an appropriate analysis. Ideology in the superstructure, he went on, is a set of various ideas according to a certain inclination, which is ultimately conditioned by its class basis (Tosaka II: 104-8). In this sense, ideology represents the historical present in which we live now, as does Gramsci's "historical bloc," which demands to be shown as the junction between one's consciousness and its historical and social structure (ibid:: 114).

To pursue this study, he distinguished the central, philosophical, question of the nature of the present as such (i.e. the logic of ideology), and the secondary, applicatory, question about journalism as a way to describe the present (i.e. the sociology of ideology) (ibid: 112-31) ${ }^{20}$. Let me concentrate on the former here, while I look at the expected role of journalism in a later section. Logically, Tosaka argued, we can hardly observe the essence of the object itself. If we dare do so, we would end up identifying a very limited amount of information as if it were the object, and jettisoning various qualities constituting the essence. Rather, Tosaka set out to derive from the object the paradigmatic character $\alpha$, which can 
represent other characters of $\beta, \gamma, \delta$, and so forth (ibid: 9-10). Tosaka's endeavor here is to jettison any vain attempt to grasp the essence by itself, and to focus on how we can give an appropriate meaning to what we see in reality-not as a façade that covers the essence, but as something that represents it. For example, Tosaka claimed that the state is particularly well understood as a character (i.e. not as modern state itself, but a particular Japanese state entailing a character of modern state) (ibid:: 17). More importantly for our current topic, he applied it to his analysis of the present and ideology. According to Tosaka, we cannot grasp human history per se, yet we are able to perceive the ideological situation at present as one, yet a paradigmatic, character of history where we can see both our consciousness and its conditions.

As such, "everydayness" or everyday life, occupies a signal place in Tosaka's scrutiny of the present. Tosaka redefined it not as a banal repetition of one's life, but as a realm of superstructural autonomy. We repeat our lifecycle, Tosaka argued, in which we plan, exercise, and reflect what we do based on certain social conditions. In such a process lies our autonomy through which we repeatedly create new needs by overcoming old conventions (Tosaka IV: 136-7). In order to appropriately interpret this process, we have to reexamine the way to perceive time, which we are inclined to divide into pieces (e.g. twenty minutes, one hour) by employing an analogy with space. Dividing time this way on the one hand, and understanding the present as a culmination of history on the other, do not contribute to our endeavor to understand time. To do so rather requires us to grasp Zeit, or period, as what is equivalent to the concept of "character." Again, we are unable to perceive history per se, as we cannot grasp the essence; however, we can apprehend a period, as do we in the case of character, as what represents history. In this sense, according to Tosaka, period is not a dividable constant, but a function of time. Crucially, Tosaka's scrutiny of character and everydayness challenged the nationalist view of the state. Against the far-fetched idealization of the Japanese State as an ethical entity long lasted since the mythological period, he insisted that any existing state typically represents a character. Even if the study of the state is carried out in an academic and abstract manner, the study reflects a character of the state in a certain temporality (Tosaka II: 17). This line of critique of Japanese nationalism is also explicated in his Japanese Ideology, which we examine in the following section.

In this section, we have looked at how Gramsci and Tosaka shared the first characteristic of Western Marxism: unique methodological developments of Marxist philosophy. With his concept of "historical bloc," Gramsci demonstrated that the superstructure is constrained, yet not determined, by the economy, and that each of them has different temporalities, as a result of which we need to exercise our autonomy to tackle still-resilient autonomous forces in the superstructure. In contrast to Gramsci who emphasized the adjective "historical" materialism, Tosaka was more adamant in characterizing himself as a materialist. However, after observing the upshot of his philosophical investigations on the superstructural terrain represented by the concepts of character and everydayness, we might wonder in what sense he was a leader of the Research Group for Materialism. ${ }^{21}$ Far from Marxist orthodoxy, and perhaps more influenced by the philosophical questions proposed by the Kyoto School to overcome Neo-Kantianism, Tosaka provided a unique development of thought about the superstructural phenomena that Western Marxists dealt with.

\section{$4 \quad$ Elements of Western Marxism (2): Focus on the Superstructure}

In the previous section, I confirmed that both Gramsci and Tosaka provide their philosophical developments of Marxism mostly in relation to the nature of the superstructure as not a mere reflection of the economic base. In this section, I look at how they explicated the characteristics of the superstructure. While Gramsci put forward his famous concept of hegemony, Tosaka elaborated the idea

Journal of World Philosophies 2 (Summer 2017): 28-41 
of custom. The remainder of this section looks at these two respectively.

\section{Gramsci: Hegemony}

After distinguishing the economic base and superstructure, Gramsci divided the superstructure into two elements: the narrowly defined state as violence and civil society. While criticizing the dominant understanding of modern states only as violence, he asserted the "spontaneous" consent of the governed, obtained in various ways in civil society, as critically important for the governance of modern states (Q12ฐ1: 1519/SPN: 12; Q26\$6: 2302/SPN: 261; Q6\$88: 763-4/SPN: 263). Such consent of the governed comprised the prime meaning among the various meanings of hegemony in Gramsci. As long as the relationship between the ruling class and the governed remains stable, hegemony persists and allows the stable exercise of governance (Q8\$191: 1056/PN3: 345). However, "[i]f the ruling class has lost consent, that is, if it no longer 'leads' but only 'rules'-it possesses sheer coercive power [...]. The crisis consists precisely in the fact that the old is dying and the new cannot be born" (Q3\$34: 311/PN2: 32-3). Gramsci called this crisis the "crisis of hegemony," or an "organic crisis" (Q13\$23: 1602/SPN: 210). The crisis stems from the uneven relationship between the ruling class and the masses, as they lose the stable, hegemonic relationship vital to governance of modern states.

It is noteworthy that Gramsci discerned such a crisis in his contemporary Italian situation. He described the Italian political situation after World War I as one in "crisis," by insisting that "[d]uring the postwar period, the hegemonic apparatus cracks and the exercise of hegemony becomes ever more difficult" (Q1ฐ48: 59/PN1: 156). This crisis revealed the failure of the Italian state to include the demands of the masses since the Risorgimento, giving fascism the opportunity to obtain mass support against the liberal government. In this situation, argued Gramsci, it was a critical task for the Italian state to include the unheard voices of the masses, and to thereby improve its lack of social mobility. Gramsci explicated this mobility as tantamount to democracy. "In the hegemonic system, there is democracy between the leading group and the groups that are led to the extent that (the development of the economy and thus) the legislation (which is an expression of that development) favors the (molecular) transition from the groups that are led [gruppi diretti] to the leading group [gruppo dirigente]" (Q8\$191: 1056/PN3: 345, translation amended TC $)^{22}$. Gramsci's task, therefore, was to recover the stable, hegemonic relationship between these groups and thus improve the rate of social mobility, which, as shown in the next section, his proposal of educational reform aims to address.

To sum up, Gramsci observed that modern states depend on the consent of the people, rather than on violence, and this enabled him to analyze how Italian politics was destabilized due to the lack of such consent. This observation differentiated him from the orthodox Marxist account of the state as solely a bourgeois means of violence, and he thus partook of the second characteristic of Western Marxism.

\section{Tosaka: Custom}

Tosaka also developed a unique theory of the superstructure with his concept of people's "custom" or Füroku. In his Thought and Custom of 1936, Tosaka examined people's everyday custom, which is constructed throughout a relationship between the social norms they take for granted, and the institutions, both formal and informal, through which people comfortably internalize those norms. In so doing, he found that this reciprocity concerning custom takes place solely within the superstructure and can hardly be portrayed by the ordinary Marxist framework of grasping superstructural phenomena only in light of the economic base ${ }^{23}$. According to him, people feel comfortable in adopting given social norms, simply 
because taking part in such conformism provides them with the feeling that they are doing a morally right thing (Tosaka 2001: 20-1). Crucially, Tosaka's theoretical contribution lies in his finding that people adopt the dominant social norms not because of false consciousness, but because doing so provides them with conformity as a justification of their actions, or as a morality that they feel comfortable with.

Tosaka's idea of custom contests two opposing views. One is the crude economism neglecting how people's custom is interrelated to social norms and institutions and emerges within the superstructural elements alone. In this sense, as Lin Shukumi succinctly remarks in her commentary, Tosaka reminds us of Althusser's concept of overdetermination ${ }^{24}$. With this concept, Louis Althusser, one of the eminent Western Marxists, argued that superstructural elements reproduce themselves by their own right without referring to economic conditions ${ }^{25}$. We find further development of his theory of this line in the idea of "ideological apparatus of the state," whereby he specified institutions such as schools, the courts, the police, and so forth, as those apparatuses that maintain and reproduce given social norms ${ }^{26}$. Lin is therefore right in pointing out that Tosaka shared with Althusser the view that the superstructure-base relationship cannot explain the autonomous reproduction (in Althusser's term, "reactivation") of superstructural elements (Lin 2001: 410).

In his masterpiece, Japanese Ideology, which was clearly inspired by Marx's German Ideology, ${ }^{27}$ Tosaka also attacked Japanese anthropologists and cultural theorists identifying people's custom as the culture of the nation that had existed since the prehistoric period. This essentialist "Japanism" was harshly condemned by him as a type of globally flourishing fascism, as it largely drew on European fascist philosophy and totalitarian ideas. All in all, Japanism was a mystification of the Japanese state with fascist ideas $^{28}$. Harootunian points out that such Japanism-a prototype of fascism-emerged in reaction to the rapid spread of modern capitalism. Fascism mobilizes people's unsatisfied desire to flatten out the necessary contradictions of capitalism demonstrated as skewed distribution of wealth, by emphasizing myths and symbols that represent the eternity of the nation (Harootunian 2001: xxix-xxxi). By employing the idea of custom as a mechanism through which people internalize the given social norms, Tosaka diagnosed the proliferation of Japanism and the mobilization of people's minds in its direction as a symptom of fascism.

By discerning that people's customs are created within the superstructure, Tosaka rejected both the crude economism and the essentialism of Japanese nationalist scholars. Like Gramsci's notion of hegemony that focuses on people's consent obtained through various institutions in civil society as the primarily important factor in the governance of modern states, Tosaka's notion of custom sheds new light on the autonomous aspect of the superstructure against orthodox Marxism, by clarifying how people take social norms for granted. In this sense, Tosaka shared the second characteristic of Western Marxism that Anderson defined: the focus on the superstructure's relative independence from the economic base.

\section{$5 \quad$ Elements of Western Marxism (3): Beyond Pessimism}

Perry Anderson claims that the third characteristic of Western Marxism is its innate pessimism due in large part to the failure of the workers' movement, the division (not unity) of theory and practice, and the impossibility of immediate revolution. Indeed, Gramsci and Tosaka were experiencing these, yet they nonetheless propose possible alternatives to the status quo while acknowledging that the task of their new kinds of Marxism appeared different from that of the old. In this section, I examine how they developed their proposals, educational reform for Gramsci and journalism for Tosaka, out of their pessimistic understanding of the present situation. 


\section{Gramsci: Educational Reform}

Gramsci was sure about the impossibility of immediate revolution under the given circumstances in Italy, where fascism seized power. Far from diminishing his intellectual endeavor, however, it rather distanced him from appealing to the Russian experience, and made him to look at the specific features of his local context. In the Prison Notebooks, he closely analyzed the Italian problems and provided remedies for them, notably the proposal for educational reform.

By examining Italian history since Renaissance, Gramsci observed the gap between the intellectuals and masses as the crux of Italian society, and began thinking of how to remedy the de facto separation between the high culture of the intellectuals and the common sense of the people. $\mathrm{He}$ considered it possible to distil from unsorted common sense a "good sense" with a more appropriate grasp of the world (Q11\$12: 1378/SPN: 325-6). In this sense, he rejected the epistemological separation between philosophy and common sense. It was from this position that he likewise rejected the sociological separation between the intellectuals and the masses. In modern society, the difference between these fundamental social groups is significantly reproduced through educational processes. In the first decade of the twentieth century, social mobility in Italy was lower than that of Germany and France ${ }^{29}$; this suggests that formal education in Italy at that time rarely remedied the gap between its elites and masses. It was for this reason that Gramsci called for educational reform to address the tremendous gap of cultural capital that had separated the two since the Renaissance. He turned his attention to how this gap affected children's achievements at the micro-level, in the classroom situation:

Undoubtedly the child of a traditionally intellectual family acquires this psycho-physical adaption more easily. Before he ever enters the classroom he has numerous advantages over his comrades, and is already in possession of attitudes learnt from his family environment: he concentrates more easily, since he is used to "sitting still," etc. [...] This is why many people think that the difficulty of study conceals some "trick" which handicaps them-that is, when they do not simply believe that they are stupid by nature (Q12\$2: 1549-50/SPN: 42-3).

What Gramsci here called an "advantage," or "trick," would in our vocabulary belong to the concept of "cultural capital." Neither the educational reform resulting from the Lateran Pacts nor the Gentile Reform attempted to flatten out this gap or assumed the possibility of increasing social mobility through education. Quite the contrary, these served to reinforce the given social formation. Gramsci's proposed educational reform aimed at addressing this problem by, for example, educating students up to sixteen years old in boarding schools-what he called "unitary schools"-and by eliminating the separation of classical and vocational schools (Q12\$1: 1534-5/SPN: 29-31; Q12ฐ2: 1547/SPN: 40). His aim was to detach students from their family backgrounds and to inculcate a certain habit of concentration in their formative study.

Implementing educational reform, Gramsci considered, would remedy the longstanding problem of the separation between the intellectuals and masses in Italy, while recruiting new intellectuals from the masses and thus increasing social mobility. He neither expected the economic transformation that would trigger the social changes, nor simply observed the impossibility of immediate revolution. Pessimism about the present circumstances rather urged this Western Marxist to closely analyze Italian problems, thereby to derive possible remedies, as his proposal for educational reform instantiates. 


\section{Tosaka: Journalism}

Tosaka also shared awareness of the impossibility of immediate and radical alteration of the present. Yet he nonetheless propounded a possible alternative to the political situation in his time, building on the principle of everydayness as a site of practice that can be configured to a different potential mode of life from the ever-triumphant fascism ( $c f$. Stolz 2013: 126). Because it is deeply rooted in people's everyday life by nature, in contrast to academism, journalism, stemming from the French word jour (i.e. day), constituted the yet underestimated configuration to reinforce ideological control and the proliferation of Japanism.

The ideas behind these nationalistic shifts, which took place after the emergence of the Second Sino-Japanese War, consisted in making the Japanese state the nation's moral entity, a movement which culminated in the deification of Emperor. Tosaka lamented that liberalism failed to block and rather helped Japanism, due to the latest form of liberalism or "cultural liberalism" that aimed to secure writers liberty to keep publishing their writings, without being disturbed by the political situations (Tosaka 1977: 17-32) ${ }^{30}$. Cultural liberals, whom Tosaka mentioned, included major thinkers from the Kyoto School, such as Nishida Kitarō, Tanabe Hajime (1885-1962), and Watsuji Tetsurō (1889-1960), rested on the alleged seriousness of their philosophy detached from the historical context of the present (Tosaka 1977: 361-8). In the last analysis, they secured their entitlement to write what they wanted at the expense of being silent about the present situation. In contrast to cultural liberalism resting on sophisticated philosophy, Tosaka appealed to people's common sense. According to him, common sense demonstrates the moral standard of a given society, apart from its usual meaning as the ordinary, and often by implication somewhat wrong, understanding of the masses (ibid: 80-1). As such, common sense reflects the underlying array of social formation (ibid:: 86). Clearly, as well as his concepts of character, everydayness, and custom,

that of common sense is in the line of Tosaka's consistent endeavor to examine what the moment in which we live now represents ${ }^{31}$.

In this context, Tosaka stressed the role of journalism. He insisted that journalism was underrated because it was said to be commercialistic and bourgeois, vulgar, and not academic. Yet journalism nevertheless represents actual everydayness of the present, in contrast to the alleged "Reality" that self-claimed realists assert according to their ideals (Tosaka IV: 137). As Schäfer succinctly points out, Tosaka understood politics not merely as macropolitics in parliament, but more importantly as a set of people's everyday activities (Schäfer 2013: 157). Confirming that everyday life possesses a political character (Tosaka III: 132), Tosaka further made a case that "basically every human being, in his capability as a human is necessarily a journalist" (Tosaka IV: 156) ${ }^{32}$.

Tosaka distinguishes the role of journalism into two functions: to report news on a daily basis and to provide social criticism. To report the news, first of all, cannot be value-free, of course. Reporting the news consists in choosing what and how to report according to given social mechanisms, whereby it expresses its historical position (ibid.: 155). When it chooses what and how to report among current issues, then it of necessity appears public and also political: it could be therefore either reactionary or progressive (ibid: : 148) ${ }^{33}$. Second, he posited journalism as social criticism. It might look similar to the role of academism, yet Tosaka judged the academism of, I assume, particularly his time, with its rigid distinction between truth and opinion, as detached from everyday life thus rendering it a-political even if the issue at stake was political (Tosaka III: 148-9). As opposed to academism as such, he considered journalism as a possible means for enlightenment. Journalism takes part in not the simple proliferation of information to the masses, but the proliferation of political knowledge closely related to their everyday life, through which they would been enlightened (Tosaka IV: 341) ${ }^{34}$.

In contrast to Gramsci's proposal of educational reform, Tosaka's hope in journalism seems to lack institutional perspective. Yet they might not be as different as they seem at first glance, because they

Journal of World Philosophies 2 (Summer 2017): 28-41 
both share a focus on how civil society (in Gramscian terms) affects people's way of thinking and acting, and on the necessity of altering it - rather than triggering revolutionary upheavals against the state organs. In this sense, Schäfer intriguingly points out that Tosaka was far from vanguardism and that closer to the belief that "the masses will rise to a revolutionary consciousness themselves through the everyday struggle in a capitalist society" (Schäfer 2013: 161). Gramsci, too, was far from vanguardism, since his proposal set out to address people's shared custom in longer terms. In this sense, as they acknowledged the impossibility of direct and immediate revolution, they elaborated their longer-term strategies to analyze the still-strong inclination of modern states to permeate people's ways of thinking and acting.

\section{Conclusion}

This article has shown the accord between Gramsci and Tosaka in terms of the three notable characteristics of Western Marxism. To recapitulate, these were: 1) methodological renovation of Marxism; 2) focus on the superstructure; and 3) political pessimism about the impossibility of immediate revolution. They respectively developed their Marxist philosophies against orthodox Marxism, in particular against economic determinism, which neglected the importance of the relative autonomy of the superstructure in modern states. Despite the lack of mutual contact and their different social, political, and geographical circumstances, the parallel between Italian and Japanese Marxists urges us to reconsider the distinctiveness of Marxism during this period.

As I note at the beginning, Western Marxism as a category confusingly entails geographical as well as theoretical notions. In this respect, Tosaka's theoretical affinity to Western Marxism suggests that the geographical notion attributed to this category might have limited its theoretical fruitfulness, which could have been discerned beyond the geographical West, against Soviet Russia representing the East. Tosaka's affinity to Western Marxism might suggest the worldwide task of Marxism at that time given the emergence of modern states as a set of ideological apparatuses at a global scale. In this sense, it would be necessary to further develop the study of Marxism in non-Western areas during this period. By doing so, as the cases of Gramsci and Tosaka suggest, it might be possible to expand the theoretical characteristics now acknowledged as belonging to Western Marxism to a broader context in which the elements of modernity such as capitalism clashed and mingled with local societies.

Takahiro Chino is a Lecturer at Waseda University, Tokyo, Japan. After obtaining his $\mathrm{PhD}$ at University College London, he was appointed a Max Weber Fellow at the European University Institute in Florence, and a Postdoctoral Fellow for the Japan Society for the Promotion of Science. He is now transforming his $\mathrm{PhD}$ thesis on Gramsci into a monograph.

1 Japanese names are shown according to the surname-name order.

2 This geographical characterization is, of course, seen in the most of the literature. See, as the classical and latest examples, Perry Anderson, Considerations on Western Marxism (London: NLB, 1976), 24-6. and Marcel van der Linden, Western Marxism and the Soviet Union: A Survey of Critical Theories and Debates Since 1917 (Leiden: Brill, 2007), 5.

3 As one anonymous review suggests, it is true that Tosaka enjoyed high popularity in the 1950s and 1960s among the cadre of the Japanese Communist Party. Yet, as the reviewer also notes, it was for the sake of idolizing Marxist martyrs who did not convert in fascist prison ( $f$. Harry Harootunian, "The Execution of Tosaka Jun and Other Tales: Historical Amnesia, Memory, and the Question of Japan's 'Postwar,"' in Ruptured Histories: War, Memory, and the Post-Cold War in Asia, 
ed. Shelia Miyoshi Jager and Rana Mitter (Cambridge, MA: Harvard University Press, 2007), 150_ 71. Studies on him have been done only intermittently since then, without even confirmation of his all works. All in all, Tosaka is still in need of serious investigation even in Japanese academia.

Some of Maruyama's works are translated into other languages. For English translations, see Masao Maruyama, Thought and Behavior in Modern Japanese Politics, ed. Ivan Morris (London: Oxford University Press, 1963); Masao Maruyama, Studies in the Intellectual History of Tokugawa Japan, trans. Mikiso Hane (Princeton: Princeton University Press, 1974).

Tosaka's selected writings have recently been published in German and in English. Jun Tosaka, Tosaka Jun: Ideologie, Medien, Alltag, ed. Fabian Schäfer (Leipzig: Leipziger Universitätsverlag, 2012); Jun Tosaka, Tosaka Jun: A Critical Reader, ed. Ken C. Kawashima, Fabian Schäfer, and Robert Stolz (New York: Cornell University East Asia Program, 2013). The latter also includes some articles that reassess the significance of Tosaka's thought.

Harry Harootunian, Overcome by Modernity: History, Culture, and Community in Interwar Japan (Princeton: Princeton University Press, 2001), xxx.

Ken C. Kawashima, Fabian Schäfer, and Robert Stolz, "Preface," in Tosaka Jun: A Critical Reader, ed. Ken C. Kawashima, Fabian Schäfer and R. Stolz (New York: Cornell University East Asia Program, 2013), vii-xiv.

Harry Harootunian, "The Postwar Genealogy of Fascism and Tosaka Jun's Prewar Critique of Liberalism," Journal of Pacific Asia 2 (1994): 103-22, here p. 105; Harry Harootunian, History's Disquiet: Modernity, Cultural Practice and the Question of Everyday Life, (New York: Columbia University Press, 2002), 240. See also Katsuya Hirano, "The Dialectic of Laughter and Tosaka's Critical Theory," in Tosaka Jun: A Critical Reader, ed. Ken C. Kawashima, Fabian Schäfer, and Robert Stolz (New York: Cornell University East Asia Program, 2013), 183; Fabian Schäfer, "The Actuality of Journalism and the Possibility of Everyday Critique," in Tosaka Jun: A Critical Reader, ed. Ken C. Kawashima, Fabian Schäfer, and Robert Stolz (New York: Cornell University East Asia Program, 2013), 173-74.

Orthodox Marxists in the Soviet Russia first labelled as "Western Marxists" non-orthodox thinkers in the West such as Georg Lukács (1885-1971) and Karl Korsch (1886-1961); yet they then adopted this category to denote their common theoretical inclinations. Douglas Kellner, "Western Marxism," in Modern Social Theory: An Introduction, ed. Austin Harrington (Oxford: Oxford University Press, 2005), 155.

10 The general description of prewar Japanese Marxism draws on Tomonaga Tairako, "Senzen Nihon Marxshugi no Toutatsuten: Miki Kiyoshi to Tosaka Jun [The Summit of Prewar Japanese Marxist Philosophy: Miki Kiyoshi and Tosaka Jun]," in Kunkan Keisei to Sekai Ninshiki [Construction of Space and Knowledge of the World], ed. Yamamuro Jun-ichi (Tokyo: Iwanami Shoten, 2006), 111-56; Yoshitomo Takeuchi, "Marxism in Japan [Nihon no Marukusu Shugl]," in Contemporary Japanese Thought [Gendai Nibon Shison Taikei] Vol. 21: Marxism II, ed. Yoshitomo Takeuchi (Tokyo: Chikuma Shobou, 1966), 7-58. For the Kyoto School, see Christopher Goto-Jones, Political Philosophy in Japan: Nishida, the Kyoto School and Co-Prosperity (London: Routledge, 2005); and Robert Carter, The Kyoto School: An Introduction (New York: State University of New York Press, 2013).

In 2016, previously unknown works of Tosaka, including those that he wrote under a pseudonym, first came to light. Yet, still there might be unknown and unedited works of him such as interviews and roundtable talks. See, Jun Tosaka, Previously Uncollected Works of Tosaka Jun [Zenshū Mishūroku Ronbun Sbun], ed. Masahiro Kitabayashi (Tokyo: Kobushi Shobō, 2016). 
1940 to September 1944, he wrote unpublished pieces and drafts, but they were burned by bombing. Jun Tosaka, Tosaka Jun Zenshü [Collected Works] 5 (Tokyo: Keisou Shobou, 1967), 517. Hereafter, quotations from Tosaka's Collected Works and are shown with volume number and page number.

Antonio Gramsci, Letters from Prison, Volume 2, ed. Frank Rosengarten, trans. Raymond Rosenthal (New York: Columbia University Press, 1994), 67.

14 Norberto Bobbio, "Gramsci and the Conception of Civil Society," in Gramsci and Marxist Theory, ed. Chantal Mouffe (London: Routledge and Kegan Paul, 1979), 34-5.

15 Following convention, quotations from Gramsci's Quaderni del carcere are shown with notebook number, passage number $(\mathbb{S}$ ) and page number, followed by the English translation where available. Regarding the frequent quotations from his texts, I use following abbreviations to refer to them:

Q Antonio Gramsci, Quaderni del carcere, ed. Valentino Gerratana (Turin: Einaudi, 1975);

SPN Antonio Gramsci, Selections from Prison Notebooks, eds. and trans. Quentin Hoare and Geoffrey Nowell Smith (London: Lawrence and Wishart, 1971);

FS Antonio Gramsci, Further Selections of the Prison Notebooks, ed. and trans. Derek Boothman, (Minneapolis: University of Minnesota Press, 1995);

PN3 Antonio Gramsci, Prison Notebooks: Vol. III, ed. and trans. Joseph Buttigieg (New York: Columbia University Press, 2007). Joseph Femia, Gramsci's Political Thought (Oxford: Clarendon Press, 1981), 121.

17 Esteve Morera, Gramsci's Historicism (London: Routledge, 1990), 74-85.

18 Fabian Schäfer, Public Opinion, Propaganda, Ideology: Theories on the Press and its Social Function in Interwar Japan, 1918-1937 (Leiden: Brill, 2012), 118-19.

19 Jun Tosaka, Sekai no Ikkan to shiteno Nibon [Japan as a Part of the World], ed. Lin Shukumi (Tokyo: Heibonsha, 2006), 186.

20 To be precise, Tosaka distinguished three stages in dealing with the present: psychology, logic, and the study of category (Tosaka III: 112-8). As he mostly focuses on logic among the three, I limit myself here to discuss the logic of ideology.

21 As one anonymous reviewer suggested, the Research Group for Materialism might be a euphemism or an umbrella term. However, it seems that Tosaka was, at least in his self-understanding, a committed materialist, as shown earlier in this section. The introductory article about the Group, published in the first number of their journal, employs the word "materialism" in order to attract both natural and social scientists, yet it was written not by Tosaka, but by Hasegawa Nyozekan, a renowned liberal journalist. See Nyozekan Hasegawa, "On the Foundation of the Research Group for Materialism," in Materialism Studies, Vol. 1 (Reprint edition) (Tokyo: Aoki Shoten, 1972), 4-7.

22 It is beyond the scope of this short essay to fully analyze Gramsci's proposal for the improvement of low social mobility. For fuller discussion, see Maurice Finocchiaro, Beyond Right and Left (New Haven: Yale University Press, 1999), 115-6; Takahiro Chino, Antonio Gramsci as an Italian Revolutionary: Gramsci's Marxism and the Crisis of Italian Democracy (Unpublished $\mathrm{PhD}$ thesis submitted to University College London, 2013), 179-207.

23 Jun Tosaka, Shisou to Fü̃oku [Thought and Custom], ed. Lin Shukumi (Tokyo: Heibonsha, 2001), 16.

24 Shukumi Lin, "Kaisetsu [Commentary]" to Jun Tosaka, Shisou to Fü̃oku [Thought and Custom] (Tokyo: Heibonsha, 2001), 410. 
Louis Althusser, "Contradiction and Overdetermination," in For Marx, trans. Ben Brewster (London: Verso, 2005), 115-6.

Louis Althusser, "Ideology and Ideological State Apparatuses," On Ideology, trans. Ben Brewster (London: Verso, 2008), 16-8. It is well known that Althusser considered Gramsci the only one who had preceded him in this endeavour (Althusser 2008: 16 n. 7).

The Research Group for Materialism translated the Adoratsky version of German Ideology, originally published in 1932, into Japanese as early as in 1936. Karl Marx German Ideology, trans. The Research Group for Materialism (Tokyo: Naukasha, 1936) <http://dl.ndl.go.jp/info:ndljp /pid/1453072> (last accessed on 3 September 2016). Like Thought and Custom, Japanese Ideology includes many stimulating pieces conveying the thrust of Tosaka's thought. Yet only three articles from this book are currently available in English and in German translations and none from Thought and Custom.

Jun Tosaka, Japanese Ideology [Nippon Ideologie Ron] (Tokyo: Iwanami Shoten, 1977), 27.

Maria Malatesta, "Introduction: The Italian Professions from a Comparative Perspective," in Society and the Professions in Italy 1860-1914, ed. Maria Malatesta, trans. Adrian Belton (Cambridge: Cambridge University Press, 2005), 18-20.

However, Tosaka did not reject liberalism at large. He seemed to suggest, although with reservation, that Kawai Eijirō (1891-1944), who continued to condemn fascism publicly (he even published a book named "Criticism of Fascism" in 1938), was an exceptionally political liberal (Tosaka 1977: 411-12).

Tosaka's view of common sense interestingly overlaps that of Gramsci, who discerns common sense as the Aristotelian doxa, which might include "good sense" of ordinary mass as a more appropriate understanding of the world (cf. Q11\$12: 1378/SPN: 325-6).

I used Schäfer's translation of this part (Schäfer 2013: 160).

Comparing the number of banned books, magazines and newspapers in 1921 and 1930 in Japan, he revealed that while the number of banned books in 1930 doubled since 1921, that of banned newspapers decreased by 60 per cent in 1930. This number shows, he argues, newspapers' inclination to become reactionary (Tosaka IV: 152).

It would shed new light on their everydayness, different from the eternalized present under Japanism, given a small yet important proviso that historical materialism is the only objective science (Tosaka IV: 35). As I explored earlier, his Marxism differs from crude economism, but he nonetheless holds the assumption of truthfulness in Marxism as a true science with the only appropriate analysis of the present-which, like the case of Gramsci's "philosophy of praxis," gives Tosaka an optimism beyond the prevailing pessimism. Further exploration of pessimism and optimism in Western Marxism is beyond the scope of this short article. Here it suffices to point out that this optimism, based on the truthfulness of Marxist science, might not have been shared with some Western Marxists such as Adorno and Benjamin. 